\title{
Christoph Althammer
}

\section{Streitgegenstand und Interesse}

Eine zivilprozessuale Studie zum deutschen und europäischen Streitgegenstandsbegriff

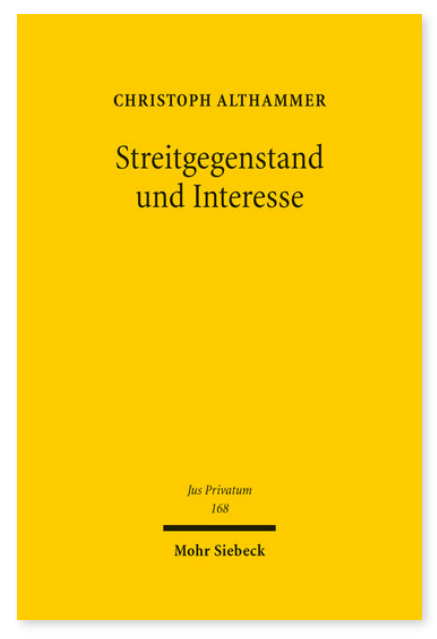

2012. XXV, 813 Seiten. JusPriv 168

ISBN 978-3-16-152251-2

DOI 10.1628/978-3-16-152251-2

eBook PDF $174,00 €$

ISBN 978-3-16-150926-1

Leinen $174,00 €$
Der Streitgegenstand stellt im deutschen Recht den Schlüsselbegriff zur Bewältigung zivilprozessualer Fragestellungen dar. Der wissenschaftliche Disput um seine richtige Definition wurde durch die Entwicklung auf europäischer Ebene in Gestalt der »Kernpunkttheorie« des EuGH neu entfacht. Obgleich diese primär die Koordinierung grenzüberschreitender Parallelverfahren nach Art. 27 EuGVO betrifft, könnte ihre dogmatische Sprengkraft langfristig Folgen für das nationale Streitgegenstandsverständnis haben. Dahinter steht auch die Frage, ob die Rechtspraxis sich bei der Ermittlung der Streitgegenstandsidentität in Zukunft allein an einer weiten sachverhaltsbestimmten Betrachtungsweise orientieren sollte, wie sie angloamerikanischen Vorstellungen entspricht, oder ob vielmehr der konkrete Interessenkonflikt der Parteien, der dem Sachverhalt seine rechtliche Prägung verleiht, den Ausschlag geben sollte. Anhand des Begriffs des Klägerinteresses entwickelt Christoph Althammer ein auf nationaler Rechtstradition beruhendes und exportfähiges Modell.

Christoph Althammer ist Professor für Bürgerliches Recht, Deutsches, Europäisches und Internationales Verfahrensrecht, Internationales Privatrecht sowie außergerichtliche Streitbeilegung an der Universität Regensburg.

Jetzt bestellen:

https://mohrsiebeck.com/buch/streitgegenstand-und-interesse-9783161522512?no_cache=1

order@mohrsiebeck.com

Telefon: +49 (0)7071-923-17

Telefax: $+49(0) 7071-51104$ 